\title{
Reply to: False-negative thyroglobulin measurement in recurrent/metastatic thyroid carcinomas
}

\author{
Eun-Kyung Park • June-Key Chung
}

Accepted: 1 November 2008 / Published online: 17 December 2008

(C) Springer-Verlag 2008

\section{Dear Sir,}

We greatly appreciate the thoughtful comments of Dr. Giovanella regarding our article investigating the clinical characteristics of patients with false-negative thyroglobulin ( $\mathrm{Tg}$ ) in the setting of positive I-131 whole-body scan [1].

In his letter, Giovanella asked if there was any difference in the preoperative serum $\mathrm{Tg}$ levels in patients who had received posttherapy I-131 whole-body scan (PT-WBS) between those who were $\mathrm{Tg}$-positive $(\mathrm{TgP})$ and those who were $\mathrm{Tg}$-negative $(\mathrm{TgN})$. Preoperative serum $\mathrm{Tg}$ levels in the $\mathrm{TgP}$ and the $\mathrm{TgN}$ patients were $395.9 \pm 1296.6$ and $302.6 \pm 1486.2 \mathrm{ng} / \mathrm{ml}$, respectively $(p=0.74)$. Thus there was no significant difference in preoperative serum $\mathrm{Tg}$ levels between the $\mathrm{TgP}$ and the $\mathrm{TgN}$ patients. Preoperative serum Tg levels were negative in $2.8 \%$ of patients in the $\mathrm{TgP}$ group and in $7.9 \%$ of patients in the $\mathrm{TgN}$ group, and this was also not significantly different $(p=0.24)$.

Giovanella also suggested that the cut-off value should be elucidated. The cut-off value was a serum $\mathrm{Tg}$ level of $2 \mathrm{ng} / \mathrm{ml}$. This was based on many other previous studies in which cut-off values of 2, 3, 5 or $10 \mathrm{ng} / \mathrm{ml}$ were used [2-4], and was selected based on clinical data in our hospital [5]. ROC analysis appears to show interdependence between PT-WBS and the Tg value and therefore PT-WBS cannot be used as a gold standard.

This reply refers to the letter to the editor at http://dx.doi.org/10.1007/ s00259-008-1005-9.

E.-K. Park ·J.-K. Chung $(\bowtie)$

Department of Nuclear Medicine,

Seoul National University Hospital,

28 Yongon-dong, Chongno-Gu,

Seoul 110-744, Korea

e-mail: jkchung@plaza.snu.ac.kr
Giovanella further stressed that one should be cautious in the measurement of $\mathrm{Tg}$ levels to avoid potential methodological biases. We agree with this comment and that is why we performed $\mathrm{Tg}$ measurements using four different assay kits in order to avoid false-negative $\mathrm{Tg}$ results. Even with this, however, we were still able to find functioning metastasis on PT-WBS in the absence of positive $\mathrm{Tg}$ in $6.3 \%$ of all patients. We would like to point out that a WBS should be undertaken routinely as a complementary modality to detect functioning recurrences and metastases regardless of the serum $\mathrm{Tg}$ results.

\section{References}

1. Park EK, Chung JK, Lim IH, Park DJ, Lee DS, Lee MC, et al. Recurrent/metastatic thyroid carcinomas false negative for serum thyroglobulin but positive by posttherapy I-131 whole body scans. Eur J Nucl Med Mol Imaging 2008. doi:10.1007/s00259008-0912-0.

2. Grant S, Luttrell B, Reeve T, Wiseman J, Wilmshurst E, Stiel J, et al. Thyroglobulin may be undetectable in the serum of patients with metastatic disease secondary to differentiated thyroid carcinoma. Follow-up of differentiated thyroid carcinoma. Cancer 1984;54: 1625-8.

3. Mazzaferri EL, Robbins RJ, Spencer CA, Braverman LE, Pacini F, Wartofsky L, et al. A consensus report of the role of serum thyroglobulin as a monitoring method for low-risk patients with papillary thyroid carcinoma. J Clin Endocrinol Metab 2003;88: 1433-41.

4. Muller-Gartner HW, Schneider C. Clinical evaluation of tumor characteristics predisposing serum thyroglobulin to be undetectable in patients with differentiated thyroid cancer. Cancer 1988;61: 976-81.

5. Chung JK, Park YJ, Kim TY, So Y, Kim SK, Park DJ, et al. Clinical significance of elevated level of serum antithyroglobulin antibody in patients with differentiated thyroid cancer after thyroid ablation. Clin Endocrinol (Oxf) 2002;57:215-21. 